\title{
- WIEDZA UCZENNIC TECHNIKUM I ABSOLWENTEK STUDIÓW WYŻSZYCH Z ZAKRESU PROFILAKTYKI I LECZENIA RAKA SZYJKI MACICY
}

\section{KNOWLEDGE OF HIGH SCHOOL STUDENTS AND UNIVERSITY GRADUATES ABOUT THE PREVENTION AND TREATMENT OF CERVICAL CANCER}

\author{
Andrzej Nowicki ${ }^{1}$, Paulina Farbicka ${ }^{2}$, Katarzyna Anczura $^{1}$ \\ ${ }^{1}$ Zakład Pielęgniarstwa Onkologicznego \\ Collegium Medicum w Bydgoszczy Uniwersytet Mikołaja Kopernika w Toruniu \\ ${ }^{2}$ Państwowa Wyższa Szkoła Zawodowa w Koszalinie \\ 10 Wojskowy Szpital Kliniczny z Polikliniką w Bydgoszczy
}

DOI: https://doi.org/10.20883/pielpol.2017.32

\section{STRESZCZENIE}

Cel. Ocena stanu wiedzy i potrzeb edukacyjnych młodzieży technikum i absolwentek studiów wyższych na temat profilaktyki i leczenia raka szyjki macicy.

Materiał i metody. Badanie przeprowadzono w Technikum nr 3 w Zielonej Górze i wśród absolwentek Uniwersytetu Zielonogórskiego. Łącznie przebadano 220 respondentek. Do badania wykorzystano autorski kwestionariusz składający się z 28 pytań. Wyniki. Ankietowane uczennice i absolwentki nie miały dostatecznej wiedzy na temat zachorowalności i śmiertelności kobiet na raka szyjki macicy w Polsce. Właściwie odpowiedziało odpowiednio $27 \%$ i $31 \%$ oraz $47 \%$ i $19 \%$ z nich. Wiedza badanych na temat profilaktyki i leczenia raka była zróżnicowana. Uczennice i absolwentki posiadały wiedzę na temat zakażenia HPV odpowiednio na poziomie $98 \%$ i $57 \%$, znały objawy raka (74\% i $39 \%$ ) oraz wiedziały, co to jest badanie cytologiczne - $83 \%$ uczennic i $39 \%$ absolwentek. Według badanych edukacja na temat raka jest niewystarczająca. Tak odpowiedziało $71 \%$ uczennic i $68 \%$ absolwentek.

Wnioski. Ogólny poziom wiedzy młodych kobiet na temat profilaktyki raka szyjki macicy jest zaledwie dostateczny. Uczennice technikum znacząco więcej wiedzą na temat epidemiologii, profilaktyki i czynników ryzyka raka szyjki macicy niż absolwentki szkoły wyższej. Młode kobiety mają świadomość ograniczonej wiedzy na temat raka szyjki macicy i wszystkie deklarują potrzebę edukacji na ten temat w ramach zajęć przed- i podyplomowych.

SŁOWA KLUCZOWE: profilaktyka, rak szyjki macicy, potrzeby edukacyjne.

\section{Wstęp}

Edukacja zdrowotna jest nieodłącznym elementem promocji zdrowia. Funkcją modelu medycznego promocji zdrowia jest nakłanianie ludzi do określonych zachowań

\section{ABSTRACT}

Aim. To assess the state of knowledge and educational needs about prevention of cervical cancer among high school students and university graduates.

Material and methods. The study was conducted at the Technical School No. 3 in Zielona Gora and among graduates of the University of Zielona Gora. 220 respondents were surveyed in total. The study used an original questionnaire consisting of 28 questions.

Results. The surveyed students and the graduates did not have sufficient knowledge about women morbidity and mortality from cervical cancer in Poland. $27 \%, 31 \%, 47 \%$, and $19 \%$ of them, respectively, answered this question correctly. Knowledge of respondents about the prevention and treatment of cancer has been diversified, young women had knowledge about HPV infection, $98 \%$ and $57 \%$ respectively, $74 \%$ and $39 \%$ of them knew the symptoms of cancer, and $83 \%$ of students and $39 \%$ of graduates knew what the cytological examination was. According to the respondents, education about cancer is insufficient, such an answer was given by $71 \%$ of students and $68 \%$ of female graduates.

Conclusions. The overall level of knowledge about cervical cancer prevention among young women is just sufficient. Schoolgirls of technical school had significantly more knowledge about the epidemiology, prevention and risk factors for cervical cancer than graduates of higher education. Young women are aware of the limited knowledge about cervical cancer and all declare the need for education on this issue in the framework of pre- and postgraduate courses.

KEYWORDS: prevention, cervical cancer, education needs.

tak, aby zapobiegać chorobom. Natomiast rolą modelu promocji zdrowia ukierunkowanego na upodmiotowienie jest zwiększanie działań na rzecz swojego zdrowia oraz tworzenie warunków, w których ludzie uczą się 
o zdrowiu i chorobach. Kolejną ważną funkcją edukacji zdrowotnej jest oddziaływanie na decydentów. To właśnie oni tworzą politykę publiczną i środowisko wspierające zdrowie. Dzięki edukacji zdrowotnej ludzie mogą zmienić swój styl życia, a zmienione jednostki mogą tworzyć wzmocnione społeczności. W ten sposób można oczekiwać zmiany społecznej, do której dąży się w promocji zdrowia [1, 2].

Uważa się, że edukacja zdrowotna prowadzona w szkole jest ważną inwestycją w zdrowie społeczeństwa. Powinna stanowić fundament polityki zdrowotnej każdego państwa. Natomiast w większości krajów osoby tworzące politykę oświatową nie traktują edukacji zdrowotnej jako istotnego zadania dla szkoły. Pokazują tradycyjne podejście, utożsamiając edukację zdrowotną z wiedzą o higienie i zdrowiu somatycznym człowieka. Myślenie to jest zupełnie inne od opisanego wyżej nowoczesnego modelu edukacji zdrowotnej [3].

W ostatnich latach w Polsce zaszły zmiany w tym zakresie. Po raz pierwszy w historii szkolnictwa edukacja zdrowotna pojawiła się w podstawach programowych kształcenia ogólnego w 1997 r. W kolejnych zmianach w 1999 r. i 2002 r. utrzymano ją jako ścieżkę edukacyjną „edukacja prozdrowotna” w szkołach wszystkich typów. W Europie takie umiejscowienie edukacji zdrowotnej jest powszechnym rozwiązaniem. Wpisanie edukacji zdrowotnej do obowiązkowych zadań szkoły zostało uznane za sukces. Natomiast wdrażanie tego nowego zadania nie jest łatwe. Konieczna jest zmiana myślenia, budowanie współpracy między nauczycielami oraz nabywanie przez nich nowych umiejętności. Wymaga to czasu i zmian infrastruktury w resorcie edukacji [4]. Istotnym elementem programu nauczania szkoły powinna być edukacja zdrowotna. Dzięki niej można propagować zdrowy styl życia całej społeczności szkolnej oraz stworzyć korzystne dla zdrowia warunki nauki dla ucznia oraz nauczycieli [3].

Rak szyjki macicy znajduje się na szóstym miejscu pod względem częstości zachorowań na nowotwory złośliwe u kobiet (3,7\%). Natomiast w populacji młodych kobiet jest drugim najczęściej występującym rakiem pod względem częstości zachorowalności i zgonów - odpowiednio 8\% i 11\% [5]. W Polsce rozpoznaje się go u około 4 tysięcy kobiet rocznie, na świecie u około pół miliona. Każdego roku prawie połowa kobiet umiera z powodu zbyt późnego wykrycia [6]. Tylko rzetelna wiedza na temat raka szyki macicy i prowadzenie badań przesiewowych w celu wykrycia wczesnego raka mogą poprawić bardzo złą sytuację epidemiologiczną w Polsce, zmniejszając w ten sposób liczbę zachorowań i zgonów z powodu tej choroby.

\section{Cel pracy}

Ocena stanu wiedzy i potrzeb edukacyjnych młodzieży technikum i absolwentek studiów wyższych na temat profilaktyki i leczenia raka szyjki macicy.

\section{Materiał i metody}

Badanie przeprowadzono w Technikum nr 3 w Zielonej Górze i wśród absolwentek Uniwersytetu Zielonogórskiego w maju i czerwcu 2014 roku. Łącznie zostało przebadanych 220 respondentek, w tym 120 uczennic technikum w przedziale wiekowym 18-20 lat oraz 100 absolwentek studiów wyższych kierunków niemedycznych w wieku 24 do 28 lat.

W pracy posłużono się metodą sondażu diagnostycznego. Narzędziem badawczym był kwestionariusz ankiety składający się z 28 pytań, podzielony na dwie części. W pierwszej zawarto pytania dotyczące wieku, stanu cywilnego i miejsca zamieszkania. W drugiej pytania związane z wiedzą na temat raka szyjki macicy. W części formalno-ewidencyjnej poinformowano respondentki o sposobie wypełniania ankiet i o celu wykorzystania kwestionariuszy. Analizy statystyczne przeprowadzono za pomocą oprogramowania statystycznego PQStat ver. 1.4.8.322. Wyniki przedstawiono w tabelach liczności i dwudzielczych. Zależności między rozkładem odpowiedzi na pytania ankiety a grupą badaną (uczennice, absolwentki) analizowano testem zależności chi ${ }^{2}$ oraz testem Fishera. Za istotne przyjęto prawdopodobieństwo testowe na poziomie $p \leqslant 0,05$ a za wysoce istotne przyjęto prawdopodobieństwo testowe na poziomie $p<0,01$.

\section{Wyniki badań}

\section{Charakterystyka badanych}

W przedziale wiekowym 18-20 lat najwięcej było uczennic w wieku 19 lat, natomiast wśród absolwentek szkoły wyższej w wieku 25 lat. W grupie uczennic wszystkie były pannami, natomiast wśród absolwentek wyższej uczelni $31 \%$ było mężatkami ( $p<0,0001)$. Więcej uczennic i absolwentek mieszkało w dużym mieście $(p=0,07)$ (Tabela 1). 
Tabela 1. Dane społeczno-demograficzne

Table 1. Socio-demographic data

\begin{tabular}{|c|c|c|c|c|c|}
\hline & $\begin{array}{l}\text { Grupa/ } \\
\text { Group }\end{array}$ & $\begin{array}{c}\text { Uczennice/ } \\
\text { Students }\end{array}$ & & $\begin{array}{c}\text { Absolwentki/ } \\
\text { Graduates }\end{array}$ & \\
\hline $\begin{array}{c}\text { Zmienna/ } \\
\text { Variable }\end{array}$ & $\begin{array}{l}\text { Wyszczególnienie/ } \\
\text { Specification }\end{array}$ & Liczba/Number & $\%$ & Liczba/Number & $\%$ \\
\hline & 18 & 60 & 50 & - & - \\
\hline & 19 & 60 & 50 & - & - \\
\hline & 20 & - & - & - & - \\
\hline Wide & 24 & - & - & 24 & 24 \\
\hline WIIEK/Age & 25 & - & - & 45 & 45 \\
\hline & 26 & - & - & 14 & 14 \\
\hline & 27 & - & - & 11 & 11 \\
\hline & 28 & - & - & 6 & 6 \\
\hline $\begin{array}{l}\text { Stan } \\
\text { cywilny/ }\end{array}$ & panna/single & 120 & 100 & 69 & 69 \\
\hline $\begin{array}{l}\text { Marital } \\
\text { status }\end{array}$ & mężatka/married & - & - & 31 & 31 \\
\hline Miejsce & duże miasto/big city & 52 & 43 & 39 & 39 \\
\hline $\begin{array}{l}\text { zamieszka- } \\
\text { nia/ }\end{array}$ & $\begin{array}{l}\text { małe miasto/small } \\
\text { city }\end{array}$ & 26 & 22 & 35 & 35 \\
\hline residence & wieś/village & 42 & 35 & 26 & 26 \\
\hline
\end{tabular}

Źródło: opracowanie własne

Source: author's own analysis

\section{Wiedza na temat epidemiologii raka szyjki macicy w Polsce}

Uczennice i absolwentki odpowiadały prawidłowo podobnie: że rak szyjki macicy wśród nowotworów dotyczących młodych kobiet jest na 2. miejscu. Prawie połowa uczennic odpowiedziała, że rocznie umiera „1500-2000” kobiet. Natomiast prawidłowej odpowiedzi udzieliło tylko 19\% absolwentek (Tabela 2).

Tabela 2. Odpowiedzi na pytania o epidemiologię Table 2. Answers to questions about the epidemiology

\begin{tabular}{|c|c|c|c|c|c|c|}
\hline \multicolumn{2}{|c|}{ Grupa/Group } & \multicolumn{2}{|c|}{$\begin{array}{c}\text { Uczennice } \\
\text { Students }\end{array}$} & \multicolumn{2}{|c|}{$\begin{array}{c}\text { Absolwentki/ } \\
\text { Graduates }\end{array}$} & \multirow{2}{*}{$p$} \\
\hline $\begin{array}{l}\text { Pytanie/ } \\
\text { Question }\end{array}$ & $\begin{array}{c}\text { Odpowiedź/ } \\
\text { Response }\end{array}$ & $\begin{array}{l}\text { Liczba/ } \\
\text { Number }\end{array}$ & $\%$ & $\begin{array}{l}\text { Liczba/ } \\
\text { Number }\end{array}$ & $\%$ & \\
\hline \multirow{4}{*}{$\begin{array}{l}\text { Rak szyjki macicy } \\
\text { w Polsce/Cervival } \\
\text { cancer in Poland }\end{array}$} & $\begin{array}{c}2 \text { w kolejności } \\
\text { zachorowalności/ } \\
2 \text { in the order of } \\
\text { morbidity }\end{array}$ & 31 & 26 & 31 & 31 & \multirow{4}{*}{$<0,05$} \\
\hline & $\begin{array}{c}3 \text { w kolejności } \\
\text { zachorowalności/ } \\
3 \text { in the order of } \\
\text { morbidity }\end{array}$ & 48 & 40 & 15 & 15 & \\
\hline & $\begin{array}{c}4 \text { w kolejności } \\
\text { zachorowalności/ } \\
4 \text { in the order of } \\
\text { morbidity }\end{array}$ & 33 & 28 & 28 & 28 & \\
\hline & $\begin{array}{c}5 \text { w kolejności } \\
\text { zachorowalności/ } \\
5 \text { in the order of } \\
\text { morbidity }\end{array}$ & 8 & 7 & 26 & 26 & \\
\hline
\end{tabular}

\begin{tabular}{ccccccc} 
Liczba kobiet & 1000 & 31 & 26 & 27 & 27 & \\
umierających & $1500-2000$ & 56 & 47 & 19 & 19 & \\
rocznie na raka & & 26 & 22 & 29 & 29 & \\
$\begin{array}{c}\text { szyjki macicy } \\
\text { w Polsce/The }\end{array}$ & $2001-2500$ & 26,0001 \\
$\begin{array}{c}\text { number of women } \\
\text { dying each year } \\
\text { from cervical }\end{array}$ & $>3000$ & 7 & 6 & 25 & 25 & \\
cancer in Poland & & & & & & \\
\hline
\end{tabular}

Źródło: opracowanie własne

Source: author's own analysis

\section{Zachowania prozdrowotne dotyczące raka szyjki macicy}

Pierwsze badanie ginekologiczne miało już za sobą $52 \%$ uczennic i $65 \%$ absolwentek wyższej uczelni. Badających się ginekologicznie częściej niż raz w roku było $40 \%$ uczennic, a tylko 6\% absolwentek. Natomiast rzadziej niż 1 raz w roku badało się $31 \%$ uczennic oraz $46 \%$ absolwentek. Papierosy nałogowo pali 34\% uczennic i 49\% absolwentek. Uczennice najczęściej rozpoczynały współżycie „między 15 a 18 rokiem życia”, natomiast absolwentki „przed 15 rokiem życia” i „między 15 a 18 rokiem życia”. Uczennice najczęściej miały „jednego partnera", natomiast absolwentki wskazywały większą liczbę partnerów („,czterech lub więcej”). Badane odpowiadały najczęściej, że ,,nie zaszczepią się”. Dla 20\% uczennic szczepionka jest zbyt droga. Zaszczepionych przeciwko HPV było po $12 \%$ uczennic i absolwentek. Uczennice częściej niż absolwentki nie stosują antykoncepcji. Większość uczennic nigdy nie stosowała antykoncepcji. Tej samej odpowiedzi udzieliło 37\% absolwentek. Antykoncepcję zawsze stosuje 10\% uczennic i tylko $11 \%$ absolwentek. Cytologii nie miało wykonanej $72 \%$ uczennic i 44\% absolwentek. Tylko 33\% absolwentek i 13\% uczennic miało wykonaną cytologię powyżej 18 roku życia (Tabela 3 ).

Tabela 3. Odpowiedzi na pytania dotyczące zachowań prozdrowotnych Table 3. Answers to questions about the healthy behaviorgraduates

\begin{tabular}{|c|c|c|c|c|c|c|}
\hline $\begin{array}{l}\text { Grupa/ } \\
\text { Group }\end{array}$ & & $\begin{array}{r}\text { Uczenni } \\
\text { Studen }\end{array}$ & ice/ & $\begin{array}{l}\text { Absolwer } \\
\text { Graduat }\end{array}$ & $\begin{array}{l}\text { ntki/ } \\
\text { tes }\end{array}$ & \\
\hline $\begin{array}{l}\text { Pytanie/ } \\
\text { Question }\end{array}$ & $\begin{array}{c}\text { Odpowiedź/ } \\
\text { Response }\end{array}$ & $\begin{array}{l}\text { Liczba/ } \\
\text { Number }\end{array}$ & $\%$ & $\begin{array}{l}\text { Liczba/ } \\
\text { Number }\end{array}$ & $\%$ & $\rho$ \\
\hline $\begin{array}{l}\text { Odbyte pierwsze badanie } \\
\text { ginekologiczne/ }\end{array}$ & tak/yes & 62 & 52 & 65 & 65 & \\
\hline $\begin{array}{l}\text { Completed the first gyneco- } \\
\text { logical examination }\end{array}$ & nie/no & 58 & 48 & 35 & 35 & $=0,05$ \\
\hline Częstotliwość badań gine- & $\begin{array}{l}<1 \times \text { w roku/ } \\
<1 x \text { a year }\end{array}$ & 18 & 15 & 31 & 30 & \\
\hline $\begin{array}{l}\text { kologicznych/ } \\
\text { The frequency of gyneco- }\end{array}$ & $\begin{array}{l}1 \times \text { w roku/ } \\
1 x \text { a year }\end{array}$ & 19 & 16 & 30 & 46 & $<0,0001$ \\
\hline logical examination & $\begin{array}{l}>1 \times \text { w roku/ } \\
>1 \times \text { a year }\end{array}$ & 25 & 40 & 4 & 6 & \\
\hline Nałogowe palenie papiero- & tak/yes & 41 & 34 & 49 & 49 & $=0.03$ \\
\hline sów/Smoking compulsively & nie/no & 79 & 66 & 51 & 51 & \\
\hline
\end{tabular}




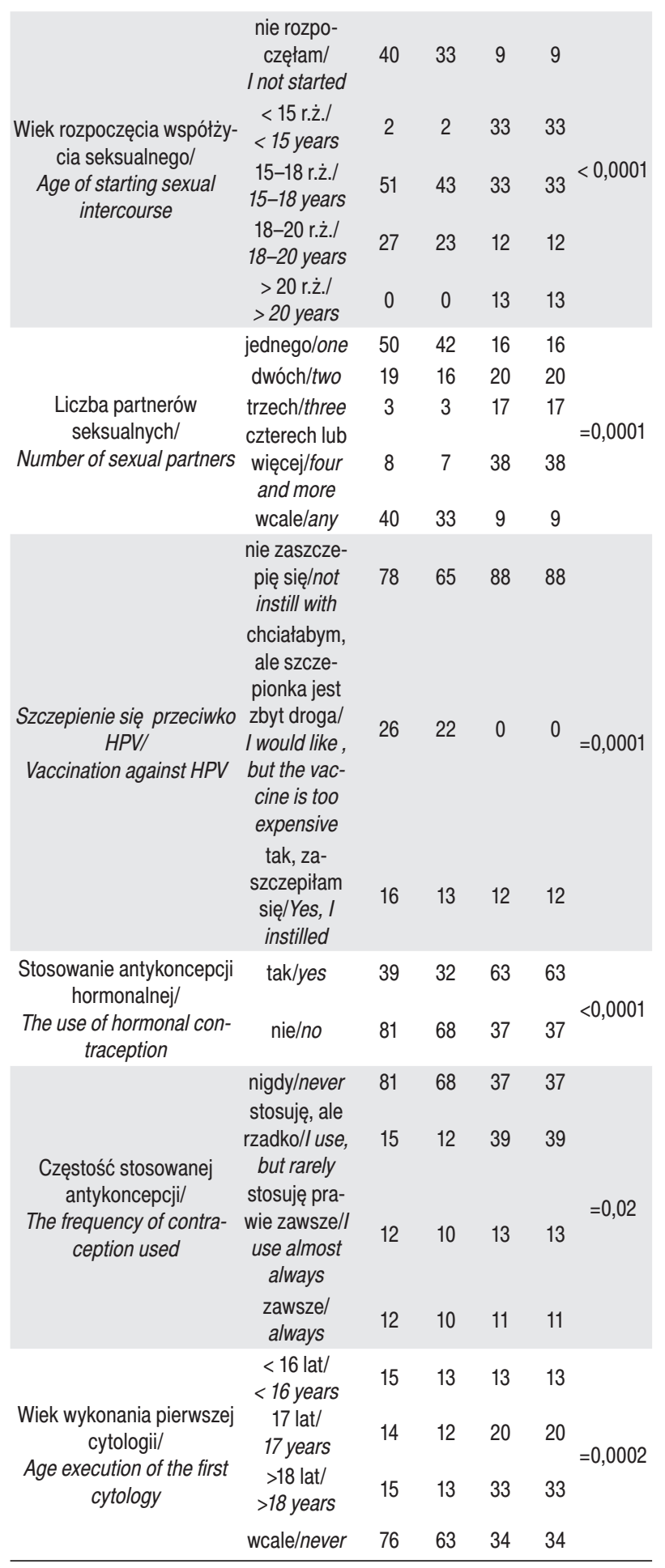

Źródło: opracowanie własne

Source: author's own analysis

\section{Wiedza na temat profilaktyki i leczenia raka szyjki macicy}

O tym, że zakażenie HPV może dotyczyć kobiet i mężczyzn, wiedziało, $66 \%$ uczennic oraz $49 \%$ absolwentek. $\mathrm{Na}$ etiologię wirusową raka szyjki macicy prawidłowo wskazało $82 \%$ uczennic i $63 \%$ absolwentek. Prawie wszystkie uczennice wskazały prawidłową odpowiedź, że krew i kontakty seksualne są przyczyną zakażenia HPV, natomiast tylko 57\% absolwentek. Informacje na temat szczepienia przeciwko HPV otrzymało od lekarza odpowiednio 31 i 28\% uczennic i absolwentek. Większość uczennic i tylko 52\% absolwentek odpowiedziała prawidłowo, że głównie dziewczęta powinny szczepić się przeciwko HPV. Przy pytaniu o objawy uczennice w większości wskazywały na poprawną odpowiedź („Nietypowe upławy i krwawienie”), natomiast tak odpowiadało tylko 39\% absolwentek. Na pytanie, czy badanie cytologiczne to wykrywanie nieprawidłowych zmian w komórkach nabłonka szyjki macicy, twierdząco odpowiadało $83 \%$ uczennic, natomiast tylko 36\% absolwentek. W większości uczennice i absolwentki odpowiadały prawidłowo, że cytologię wykonuje się przy użyciu wziernika ginekologicznego. Tak odpowiedziała jednak większa liczba uczennic niż absolwentek. Większość uczennic i absolwentek wiedziało, że program wczesnego wykrywania szyjki macicy to „wykonanie cytologii raz na 3 lata po 25 roku życia" (Tabela 4).

Tabela 4. Odpowiedzi na pytania dotyczące profilaktyki i leczenia (więcej niż jedna odpowiedź może być prawidłowa)

Table 4. Answers to questions about the prevention and treatment (more than one answer may be correct) graduates

\begin{tabular}{|c|c|c|c|c|c|c|}
\hline \multicolumn{2}{|c|}{$\begin{array}{l}\text { Grupa/ } \\
\text { Group }\end{array}$} & \multicolumn{2}{|c|}{$\begin{array}{l}\text { Uczennice/ } \\
\text { Students }\end{array}$} & \multicolumn{2}{|c|}{$\begin{array}{l}\text { Absolwentki/ } \\
\text { Graduates }\end{array}$} & \multirow[b]{2}{*}{$p$} \\
\hline Pytanie/Question & $\begin{array}{c}\text { Odpowiedź/ } \\
\text { Response }\end{array}$ & $\begin{array}{l}\text { Liczba/ } \\
\text { Number }\end{array}$ & $\%$ & $\begin{array}{l}\text { Liczba/ } \\
\text { Number }\end{array}$ & $\%$ & \\
\hline \multirow{2}{*}{$\begin{array}{l}\text { Czy zakażenie HPV } \\
\text { dotyczy kobiet } \\
\text { i mężczyzn?/ } \\
\text { Do HPV infections } \\
\text { affect women } \\
\text { and men? }\end{array}$} & tak/yes & 79 & 66 & 49 & 49 & \multirow{2}{*}{$=0,01$} \\
\hline & nie/no & 41 & 34 & 51 & 51 & \\
\hline \multirow{4}{*}{$\begin{array}{l}\text { Choroby związane } \\
\text { z zakażeniem HPV/ } \\
\text { Diseases asso- } \\
\text { ciated with HPV } \\
\text { infection }\end{array}$} & $\begin{array}{c}\text { rak gardła/throat } \\
\text { cancer }\end{array}$ & 1 & 1 & 5 & 5 & \multirow{4}{*}{$<0,0057$} \\
\hline & $\begin{array}{l}\text { rak szyjki macicy/ } \\
\text { cervical cancer }\end{array}$ & 97 & 81 & 63 & 63 & \\
\hline & $\begin{array}{c}\text { rak odbytu/anal } \\
\text { cancer }\end{array}$ & 2 & 2 & 8 & 8 & \\
\hline & $\begin{array}{c}\text { wszystkie wymie- } \\
\text { nione/all of the } \\
\text { above }\end{array}$ & 20 & 17 & 24 & 24 & \\
\hline \multirow{3}{*}{$\begin{array}{c}\text { Droga zakażenia } \\
\text { HPV/Route of HPV } \\
\text { infection }\end{array}$} & $\begin{array}{l}\text { krew, kontakty } \\
\text { seksualne/blood, } \\
\text { sexual contacts }\end{array}$ & 117 & 98 & 57 & 57 & \multirow{3}{*}{$=0,0001$} \\
\hline & ślina/saliva & 1 & 1 & 15 & 15 & \\
\hline & $\begin{array}{c}\text { droga kropelkowa/ } \\
\text { droplet route }\end{array}$ & 2 & 2 & 28 & 28 & \\
\hline $\begin{array}{l}\text { Informacja od leka- } \\
\text { rza rodzinnego na } \\
\text { temat szczepienia } \\
\text { przeciwko HPV/ } \\
\text { Information from }\end{array}$ & tak/yes & 37 & 31 & 28 & 28 & \multirow[t]{2}{*}{$=0,64$} \\
\hline $\begin{array}{c}\text { your family doctor } \\
\text { about the HPV } \\
\text { vaccination }\end{array}$ & nie/no & 83 & 69 & 72 & 72 & \\
\hline
\end{tabular}




\begin{tabular}{|c|c|c|c|c|c|c|}
\hline \multirow{2}{*}{\multicolumn{2}{|c|}{$\begin{array}{cc} & \text { kobiety }>50 \text { r.ż./ } \\
\text { Kto może zaszcze- } & \text { women > } 50 \text { years } \\
\text { pić się przeciwko } & \text { kobiety w ciąży/ } \\
\text { HPV/ } & \text { pregnant women } \\
\text { Who can get } & \text { dziewczęta od } 11\end{array}$}} & 17 & 14 & 16 & 16 & \multirow{3}{*}{$<0,0001$} \\
\hline & & 11 & 9 & 32 & 32 & \\
\hline $\begin{array}{c}\text { vaccinated against } \\
\text { HPV }\end{array}$ & $\begin{array}{c}\text { dziewczęta od } 11 \\
\text { do } 12 \text { r.ż./ girls } \\
11-12 \text { yeras }\end{array}$ & 92 & 77 & 52 & 52 & \\
\hline \multirow{3}{*}{$\begin{array}{l}\text { Objawy raka szyjki } \\
\text { macicy/The symp- } \\
\text { toms of cervical } \\
\text { cancer }\end{array}$} & $\begin{array}{l}\text { nieregularne mie- } \\
\text { siączki, spadek } \\
\text { masy ciała/irregu- } \\
\text { lar menstruation, } \\
\text { weight loss }\end{array}$ & 11 & 9 & 43 & 43 & \multirow{3}{*}{$<0,0001$} \\
\hline & $\begin{array}{l}\text { nietypowe upławy } \\
\text { i krwawienie/unu- } \\
\text { sual vaginal whites } \\
\text { and bleeding }\end{array}$ & 89 & 74 & 39 & 39 & \\
\hline & $\begin{array}{l}\text { ból brzucha, } \\
\text { bardzo obfite } \\
\text { bolesne mie- } \\
\text { siączki/abdominal } \\
\text { pain, rich painful } \\
\text { menstruation }\end{array}$ & 20 & 17 & 28 & 28 & \\
\hline \multirow{3}{*}{\multicolumn{2}{|c|}{$\begin{array}{c}\begin{array}{c}\text { Co to jest badanie metoda obrazowa } \\
\text { cytologiczne/What żeńskich narzą- } \\
\text { is a cytological } \\
\text { examination } \\
\text { dów płciowych/ } \\
\text { radiology method } \\
\text { of female genital } \\
\text { mutilation } \\
\text { metoda badania } \\
\text { poziomu żeńskich } \\
\text { hormonów płcio- } \\
\text { wych/method of } \\
\text { testing the level of } \\
\text { female sex hor- } \\
\text { mones }\end{array}\end{array}$}} & 100 & 83 & 39 & 39 & \multirow{3}{*}{$<0,0001$} \\
\hline & & 14 & 12 & 28 & 28 & \\
\hline & & 6 & 5 & 33 & 33 & \\
\hline \multirow{3}{*}{$\begin{array}{c}\text { Sposób } \\
\text { wykonania cyto- } \\
\text { logii/ } \\
\text { Procedure cytology }\end{array}$} & $\begin{array}{l}\text { przy pomocy } \\
\text { wziernika pobie- } \\
\text { ranie materiału } \\
\text { komórkowego } \\
\text { z szyjki macicy/ } \\
\text { using a speculum } \\
\text { collection of } \\
\text { cellular material } \\
\text { from the cervix }\end{array}$ & 111 & 93 & 63 & 63 & \multirow{3}{*}{$<0,0001$} \\
\hline & $\begin{array}{l}\text { badanie składu } \\
\text { moczu kobiety/ } \\
\text { examination of } \\
\text { the women's urine } \\
\text { composition }\end{array}$ & 2 & 2 & 25 & 25 & \\
\hline & $\begin{array}{l}\text { rentgen macicy } \\
\text { z użyciem kontra- } \\
\text { stu/X-ray of the } \\
\text { uterus with the } \\
\text { use of contrast }\end{array}$ & 7 & 6 & 12 & 12 & \\
\hline
\end{tabular}

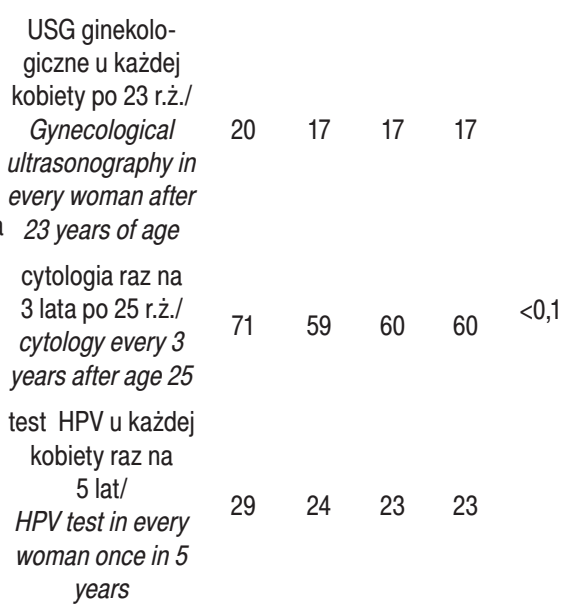

Źródło: opracowanie własne

Source: author's own analysis

\section{Działania edukacyjne w zakresie raka szyjki macicy}

Edukacja na temat raka szyjki macicy nie jest wystarczająca według $71 \%$ uczennic i $68 \%$ absolwentek. Większość uczennic i absolwentek odpowiadało podobnie, że edukacja na temat profilaktyki raka szyjki macicy powinna odbywać się zarówno w szkole, jak i na studiach. Według ankietowanych najwięcej można się dowiedzieć o raku szyjki macicy na lekcjach biologii i spotkaniach z pielęgniarką (Tabela 5).

Tabela 5. Odpowiedzi na pytania dotyczące edukacji Table 5. Answers to questions about education

\begin{tabular}{|c|c|c|c|c|c|c|}
\hline \multicolumn{2}{|l|}{$\begin{array}{l}\text { Grupa/ } \\
\text { Group }\end{array}$} & \multicolumn{4}{|c|}{$\begin{array}{c}\text { Uczennice/ Absolwentki/ } \\
\text { Students Graduates }\end{array}$} & \multirow{2}{*}{$p$} \\
\hline Pytanie/Question & $\begin{array}{l}\text { Odpowiedźl } \\
\text { Response }\end{array}$ & $\begin{array}{l}\text { Liczba/ } \\
\text { Number }\end{array}$ & $\%$ & $\begin{array}{l}\text { Liczba/ } \\
\text { Number }\end{array}$ & $\%$ & \\
\hline $\begin{array}{l}\text { Czy edukacja na temat } \\
\text { raka szyjki macicy jest } \\
\text { wystarczająca/Educa- } \\
\text { tion about cervical } \\
\text { cancer, whether it is } \\
\text { enough }\end{array}$ & tak/yes & 35 & 29 & 32 & 32 & $<0,01$ \\
\hline $\begin{array}{l}\text { Edukacja na temat } \\
\text { profilaktyki raka po- } \\
\text { winna odbywać się na } \\
\text { lekcjach w szkole i na } \\
\text { studiach?/ } \\
\text { Education about can- } \\
\text { cer prevention should } \\
\text { be lessons in school } \\
\text { and college }\end{array}$ & tak/yes & 102 & 85 & 85 & 15 & $=1,0$ \\
\hline
\end{tabular}




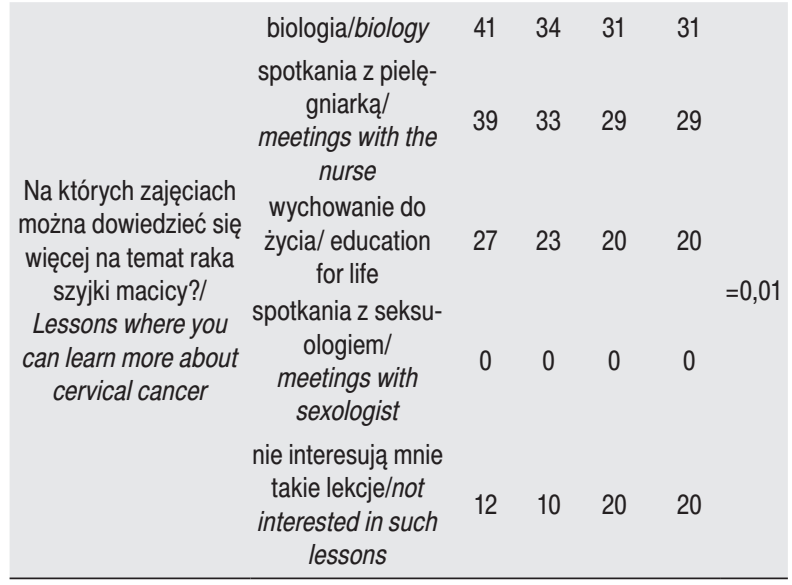

Źródło: opracowanie własne

Source: author's own analysis

\section{Dyskusja}

Zachorować na raka szyjki macicy może każda kobieta. Unikając czynników ryzyka, szczepiąc się przeciwko HPV, stosując poprawne zachowania zdrowotne, a także samoobserwację i regularną cytodiagnostykę, kobiety są w stanie uniknąć zachorowania.

Z badań własnych wynika, że uczennice i absolwentki mają małą wiedzę na temat epidemiologii raka szyjki macicy. Co druga uczennica i tylko co trzecia absolwentka wiedziały, że rak szyjki macicy - wśród nowotworów atakujących młode kobiety - jest na drugim miejscu zachorowalności w Polsce. Natomiast jeżeli chodzi o liczbę kobiet umierających na raka szyjki macicy, to wiedza była również niewystarczająca. Zaledwie co czwarta absolwentka i co druga uczennica wiedziały, ile kobiet umiera rocznie w Polsce. Ponad połowa ankietowanych w obydwu grupach była badana przez ginekologa po rozpoczęciu współżycia. W badaniach przeprowadzonych wśród łódzkich studentek, których średnia wieku wynosiła 21,6 lat więcej, $75 \%$ kobiet ma za sobą pierwszą wizytę u ginekologa [7]. Badania profilaktyczne należy rozpocząć w przeciągu 3 lat od pierwszego stosunku płciowego, jednak nie później niż w 21. roku życia [8]. Niezależnie od wieku nieco więcej niż połowa kobiet $z$ obu grup była badana przez ginekologa raz na dwa lata lub częściej. Wyniki innych analiz są mniej korzystne. Pokazują, że niewielka liczba kobiet planuje świadomie badania i poddaje się im systematycznie zgodnie z zaleceniami lekarza czy położnej [9]. Inni autorzy podają, że starsze kobiety były na okresowych badaniach u lekarza ginekologa średnio 8,6 lat później niż obecnie młode kobiety [10]. Badaniom częściej poddają się kobiety lepiej wykształcone, z wyższym wynagrodzeniem za pracę, mieszkanki miast i osoby o dobrym stanie zdrowia [9].
Z badań własnych wynika, że co trzecia uczennica i co druga absolwentka paliła papierosy. Podobne wyniki podali inni autorzy. Wśród palących, aż 1/3 pali około 20 papierosów dziennie $[9,11,12]$. Palenie papierosów sprzyja zakażeniu wirusem brodawczaka ludzkiego, a w związku z tym zwiększa się możliwość rozwoju raka szyjki macicy. Stwierdzono dwukrotny wzrost ryzyka zakażenia wirusem u palących kobiet [13].

Wśród badanych kobiet większość rozpoczęła współżycie pomiędzy 15 a 18 rokiem życia. Tylko blisko co czwarta osoba z obu grup nie miała doświadczeń seksualnych. Natomiast inni dowodzą, że niewiele kobiet poniżej 17. roku życia ma za sobą inicjację seksualną [12]. Autorzy wskazują na co najmniej dwukrotne większe względne ryzyko rozwoju raka przedinwazyjnego u chorych HPV-ujemnych, które rozpoczęły współżycie płciowe w wieku lat 16 lub wcześniej [14]. Z badań klinicznych przeprowadzonych w Indiach wynika, że względny współczynnik ryzyka rozwoju raka szyjki macicy u kobiet, które pierwszy stosunek płciowy odbyły przed 12. rokiem życia, jest znacznie wyższy niż u kobiet, które odbyły go po 18. roku życia. [10]. Rak szyjki macicy rzadko występuje u zakonnic żyjących w celibacie, a częściej u prostytutek. Aktywność seksualna, niższy wiek pierwszego stosunku oraz większa liczba partnerów powodują wzrost ryzyka zakażenia [13].

Częsta zmiana partnerów seksualnych ma istotny wpływ na wzrost ryzyka zakażenia HPV i powstania zakażenia o charakterze przewlekłym. To w konsekwencji może prowadzić do rozwoju nowotworu [15]. Przeprowadzone badanie pokazuje, że tylko połowa badanych wie, iż istnieje zależność pomiędzy częstą zmianą partnerów seksualnych a ryzykiem powstania nowotworu. Podobne wyniki uzyskali inni autorzy w badaniu przeprowadzonym w grupie 277 studentek z rzeszowskich uczelni [16].

W obu grupach aż ponad połowa młodych kobiet nie zaszczepiłaby się przeciwko HPV w wieku młodzieńczym. Szczepienie przeciwko HPV zostało wprowadzone w Polsce dopiero w 2007 roku. Oceny skuteczności szczepionki będzie można dokonać dopiero po upływie 15-20 lat. Szczepienie, jako element profilaktyki pierwotnej raka szyjki macicy, chroni w 75\% przed rakiem płaskonabłonkowym i w 96\% przed gruczolakorakiem [17]. Szczepienie przeciwko zakażeniu onkogennymi typami HPV może mieć ogromny wpływ na zapobieganie zakażeniom i rozwojowi zmian przedrakowych i raka szyjki macicy. Wśród badanych kobiet ponad połowa nie stosowała hormonalnych środków antykoncepcyjnych. Także według innych źródeł większość kobiet nie stosuje środków hormonalnych w celu antykoncepcji [12]. 
Badania prowadzone na terenie województwa małopolskiego i podkarpackiego pokazują, że najliczniej na badania cytologiczne przynajmniej raz w roku zgłaszają się kobiety z wykształceniem średnim [18]. Natomiast w województwie podkarpackim coroczną cytologię wykonują głównie kobiety z licencjatem lub wykształceniem wyższym. Niepokojący jest fakt, iż ponad połowa badanych nie wykonała cytologii ani razu [19]. Podobnie wynika z badań własnych. Większość uczennic i prawie połowa absolwentek nie wykonała jeszcze badania cytologicznego. Uczennice miały dużą wiedzę na temat metody wykonywania badania cytologicznego, natomiast dużo gorszą wiedzę miały absolwentki. Tylko co trzecia z nich wie, jak wykonuje się prawidłowo badanie cytologiczne. Ponad połowa absolwentek i prawie wszystkie uczennice uznały zakażenie HPV za główną przyczynę raka szyjki macicy. U innych tylko 13\% kobiet podało infekcje HPV jako czynnik ryzyka przyczyniający się do zachorowania na raka szyjki macicy [17]. Kobiety znają główne czynniki ryzyka zachorowania na raka szyjki macicy, takie jak: zakażenie HPV, duża liczba partnerów, wczesne rozpoczęcie współżycia seksualnego. Inne czynniki ryzyka są rzadziej wymieniane [2023]. Wyniki uzyskane w badaniu własnym są podobne.

Większość uczennic i absolwentek nie otrzymała informacji na temat szczepienia się przeciwko HPV od lekarza rodzinnego. Przeważająca ilość uczennic i połowa absolwentek wiedziała, kto może być zaszczepiony.

Tylko połowa uczennic i absolwentek znała program profilaktyczny wykrywania wczesnego raka szyjki macicy. Natomiast u innych autorów większość badanych kobiet w wieku 25-55 lat słyszała o programie profilaktyki oraz wiedziała, na czym ten program polega [24]. Kobiety uczestniczące w programie profilaktyki raka szyjki macicy mają świadomość konieczności okresowego zgłaszania się do ginekologa celem wykonania wymazu cytologicznego [7]. Istnieje potrzeba większego propagowania informacji na temat profilaktyki raka szyjki macicy oraz informowania o istnieniu Ogólnopolskiego Programu Profilaktyki Raka Szyjki Macicy. Właściwie prowadzona edukacja zdrowotna wpływa na wiele kobiet, które deklarują udział w badaniach cytologicznych [11].

Z badań własnych wynika, że edukacja na temat raka szyjki macicy jest niewystarczająca, a poziom wiedzy jest niedostateczny. Z analiz innych autorów wynika, że kobiety uważają media za główne źródło wiedzy na temat raka szyjki macicy [18]. Kobiety z Podkarpacia wiedzę o badaniach cytologicznych czerpią z imiennych zaproszeń na cytologię [5]. Edukacja na temat raka szyjki macicy powinna odbywać się również w szkole i na studiach. Prawie wszystkie badane z obu grup są zainteresowane takimi lekcjami. Co trzecia uczennica i absolwentka deklarowała, że chciałyby zdobywać wiedzę na temat raka szyjki macicy na lekcjach biologii oraz spotkaniach z pielęgniarką.

W świetle naszych wyników badań wydaje się konieczne zwiększenie edukacji zdrowotnej w zakresie profilaktyki raka szyjki macicy, ale niezbędna jest też aktywna postawa młodych kobiet. Zarówno wyniki badań własnych, jak i wyniki innych autorów wskazują na to, że młode kobiety posiadają zaledwie dostateczną wiedzę na temat profilaktyki raka szyjki macicy. Należy położyć większy nacisk na oddziaływania edukacyjne lekarza rodzinnego, lekarza ginekologa i położnej, ponieważ wiedza na temat profilaktyki raka szyjki macicy przekłada się na udział młodych kobiet w badaniach profilaktycznych wykrywających raka.

\section{Wnioski}

1. Ogólny poziom wiedzy młodych kobiet na temat profilaktyki raka szyjki macicy jest zaledwie dostateczny.

2. Uczennice technikum znacząco więcej wiedzą na temat epidemiologii, profilaktyki i czynników ryzyka raka szyjki macicy niż absolwentki szkoły wyższej.

3. Młode kobiety mają świadomość ograniczonej wiedzy na temat raka szyjki macicy i wszystkie deklarują potrzebę edukacji na ten temat w ramach zajęć przed- i podyplomowych.

\section{Piśmiennictwo}

1. Woynarowska B, Sokołowska M. Ścieżka edukacyjna edukacja prozdrowotna i promocja zdrowia w szkole. Warszawa: KOWEZ; 2001

2. Cox J. Wytyczne profilaktyki raka szyjki macicy: znaczenie częstotliwości badań. Część 1. Ginekol. Dypl. 2006; 7: 13-19.

3. Przestrzelska M, Knihinicka-Mercik Z, Kazimierczak I i wsp. Zachowania zdrowotne kobiet $w$ profilaktyce nowotworu szyjki macicy i sutka. Onkol Pol. 2006; 9: 172-175.

4. Parazzini F, Chatenoud L, La Vecchia C, et al. Determinants of risk of invasive cervical cancer in young women. $\mathrm{Br} J$ Cancer. 1998; 77: 838-841.

5. Didkowska J, Wojciechowska U. Nowotwory złośliwe w Polsce w 2013 roku. Warszawa: Centrum Onkologii-Instytut im. M. Skłodowskiej-Curie; 2015.

6. Spaczyński M, Kędzia W, Nowak-Markwitz E. Rak szyjki macicy. Profilaktyka, diagnostyka i leczenie. Warszawa: Wydawnictwo Lekarskie PZWL; 2009; 187-192.

7. Shields T, Brinton L, Burk R, et al. A case-control study of risk factors for invasive cervical cancer among U. S. women exposed to oncogenic types of human papillomavirus. Cancer Epidemiol Biomarkers Prev. 2004; 13: 1574-1582.

8. Kirwan J, Herrington C. Zakażenie wirusem brodawczaka ludzkiego, a rak szyjki macicy. Med Prakt Ginekol Położ. 2002; 3: 21-22.

9. Schiffman M, Bauer H, Hoover R et al. Epidemiologic evidence shoving that human papillomavirus infection causes most cervical intraepithelial neoplasia. J Natl Cancer Inst. 1993; 85: 958-964. 
10. Nawarra-Karowicz D, Kowalska-Koprek U, Karowicz-Bilińska A. Ocena wystąpienia czynników ryzyka zakażenia wirusem brodawczaka ludzkiego (HPV) oraz stopnia jego onkogenności wśród mieszkanek wsi. Prz Menopauz 2005; 4: 22-31.

11. Kądziołka J, Barnaś E, Domka E, Grzegorczyk J, Bojar I. The level of knowledge presented by students from universities of Rzeszów regarding cervical cancer threat and its risk factors. W: Wdowiak L, Kruk W, Binkowska-Bury M. (red.). Public Health and Research. Lublin: Wydawnictwo Neurocentrum; 2009: 183-193.

12. Rekomendacje Polskiego Towarzystwa Ginekologicznego dotyczące szczepienia przeciwko zakażeniom HPV. Ginekol Pol. 2007; 78: 185-190.

13. Iwanowicz-Palus G, Adamska-Kuźmicka I, Bień A, Stadnicka G. Wiedza i postawy kobiet wobec profilaktyki raka szyjki macicy. Piel XXIw 2010; 32/33: 9-16.

14. Piskorz M, Zielińska A, Józefiak A i wsp. Wiedza na temat profilaktyki raka szyjki macicy kobiet uczestniczących w Ogólnopolskim Programie Profilaktyki Raka Szyjki Macicy. Przegl Ginekol Pol. 2005; 5: 141-143.

15. Basta A. Zakażenie wirusem brodawczaka ludzkiego a rak szyjki macicy. Med Prakt Ginekol Położ 2002; 5: 36-48.

16. Klimek R. Jatrogenne przyczyny raka szyjki macicy w Polsce. Prz Ginekol Położ 2005; 2: 55-59.

17. Mikołajczyk K, Żaba R. Zakażenia HPV jako problem kliniczny. Przew Lek 2005; 5: 38-47.

18. Wright TC Jr, Massad S, Dunton CJ et al. 2006 consensus guidelines for the management of women with cervical intraepithelial neoplasia or adenocarcinoma in situ. Am J Obstet Gynecol 2007; 197: 340-345.

19. Barnaś E, Borowiec-Domka E, Kądziołka J, Grzegorczyk J. Factors affecting the response - rate to cytology examinations of women in the Subcarpathian region. National Programme of Cervical Cancer Prophylaxis. Probl Hig i Epidem 2008; 89: 482-486.

20. Schiffman M, Wentzensen N. From human papillomavirus to Cervical Cancer. Obstetric \& Gynecology 2010; 116: 177-185.
21. Wright TC Jr, Massad S, Dunton CJ et al. 2006 consensus guidelines for the management of women with cervical intraepithelial neoplasia or adenocarcinoma in situ. Am J Obstet Gynecol 2007; 197: 340-345.

22. Spaczyński M, Nowak-Markwitz E, Januszek-Michalecka L i wsp. Profil socjalny kobiet a ich udział w Programie Profilaktyki i Wczesnego Wykrywania Raka Szyjki Macicy w Polsce. Gin Pol 2009; 80: 833-838.

23. Spaczyński M, Michalska M, Januszek-Michalecka L. Centralny Ośrodek Koordynujący. Raport z realizacji Populacyjnego Programu Profilaktyki i Wczesnego Wykrywania Raka Szyjki Macicy za okres 1.01.2008 do 31.12.2008. Gin Pol 2009; 80: 220-226.

24. Rokita W, Stanisławska M, Spaczyński M i wsp. Elektrochirurgia zmian szyjki macicy i jej miejsce w profilaktyce raka szyjki macicy. Gin Pol 2009; 80: 856-860.

Artykuł przyjęty do redakcji: 21.07.2016

Artykuł przyjęty do publikacji: 16.11.2016

Źródło finansowania: Praca nie jest finansowana z żadnego źródła. Konflikt interesów: Autorzy deklarują brak konfliktu interesów.

Adres do korespondencji:

Andrzej Nowicki

ul. Łukasiewicza 2

85-801 Bydgoszcz

tel.: 602353210

e-mail: anow1_xl@wp.pl

Zakład Pielęgniarstwa Onkologicznego

Collegium Medicum w Bydgoszczy Uniwersytet Mikołaja Kopernika w Toruniu 